\title{
Production and partial characterization of protease from Pseudomonas aeruginosa and Bacillus subtilis isolated from domestic waste dumpsite
}

\author{
${ }^{1 *}$ Tsado A. Ndarubu, ${ }^{2}$ Jiya A. Gboke, ${ }^{1}$ Ibrahim A. Habiba, ${ }^{3}$ Gana David, ${ }^{1}$ Zubairu Rakiya, \\ ${ }^{4}$ Danazumi Nathaniel, ${ }^{1}$ Mohammed A. Saba, ${ }^{1}$ Aliyu Muhammad, and ${ }^{1}$ Akinniran C. Sunday
}

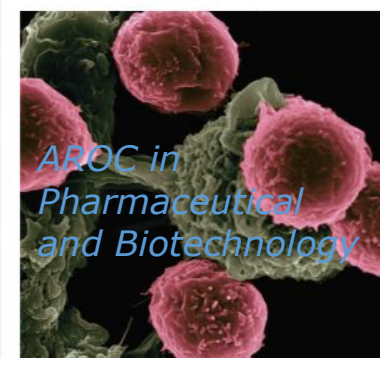

${ }^{1}$ Department of Biological sciences, Niger State polytechnic, P. M. B 01, Zungeru, Niger State, Nigeria.

2Department of Biological Sciences, Federal Polytechnic, Bida, Niger State, Nigeria.

${ }^{3}$ Department of Geography and Environmental Management, University of Abuja, Nigeria.

${ }^{4}$ Department of Chemical Science, Federal Polytechnic, Bida, Niger State, Nigeria

\author{
*Corresponding author \\ Tsado A. Ndarubu \\ Email: infoamosndarubu@gmail.com \\ Mobile-+2348032920909
}

\section{ABSTRACT}

Background: Microorganisms are the leading source of industrial proteases. As a result of this, researchers are searching for new microbial strain with novel characteristic for protease production. Methods: In this study, some microbial strains were isolated from a soil sample obtained from domestic waste dumpsite. The isolate was screened for protease activity using casein as substrate. The proteolytic isolates were identified and used for protease production. The optimum $\mathrm{pH}$ and temperature as well as kinetic parameters of the enzyme were determined to predict their suitable industrial applications. Results: Pseudomonas aeruginosa and Bacillus subtilis were identified to be active proteases producers. The optimum temperature of the Pseudomonas aeruginosa and Bacillus subtilis were both recorded at $50^{\circ} \mathrm{C}$ while the optimum $\mathrm{pH}$ of Pseudomonas aeruginosa and Bacillus subtilis were recorded at 8.0 and 9.0 respectively. The $\mathrm{K}_{\mathrm{m}}$ and $\mathrm{V}_{\mathrm{max}}$ of protease produced from Pseudomonas aeruginosa were $222.22 \mathrm{U} / \mathrm{ml}$ and $0.625 \mathrm{mg} / \mathrm{ml}$ respectively while the $\mathrm{K}_{\mathrm{m}}$ and $\mathrm{V}_{\max }$ were proteases produced from Bacillus subtilis were $135.13 \mathrm{U} / \mathrm{ml}$ and $0.402 \mathrm{mg} / \mathrm{ml}$ respectively. Conclusion: The results in this study suggest that domestic waste dumpsite could be a potential source of proteolytic isolates of novel characteristic.

Keywords: Domestic waste, Partial characterization, protease Pseudomonas aeruginosa and Bacillus subtilis Received: 05 June 2021, Revised: 07 July 2021, Published: 22, July 2021

Citation: Tsado A. N., Jiya, A.G., Ibrahim, A.H., Gana, D., Zubairu, R., Danazumi, N., Mohammed, A.S., Aliyu, M., and Akinniran, C.S. (2021). Production and partial characterization of protease from Pseudomonas aeruginosa and Bacillus subtilis isolated from domestic waste dumpsite.

AROC in Pharmaceutical and Biotechnology, 01(01);26-33

\subsection{Introduction}

In recent years, new innovations are opening up new avenues in the areas of industrial biotechnology in which many chemical processes are replaced by enzymatic methods. Proteases are a group of enzymes with a wide range of applications and account for $40-60 \%$ of the total enzyme sales [1]. Proteases refer to a group of enzymes whose catalytic function is to hydrolyze peptide bonds of proteins. They are also called proteolytic enzymes or proteinases. They are ubiquitous in nature and perform a major role with respect to their applications in both physiological and commercial fields [2]. They are used extensively in the detergent, leather, pharmaceutical, and food 
industries. Proteases of industrial-scale are mostly produced by microorganisms although there are some produced by plants and animals [3]. The total value of protease covers $60 \%$ of the total worldwide enzyme sales. This is because microbial properties exhibit advantageous properties that are useful for biotechnological processes such as their resilience under extreme temperature, $\mathrm{pH}$ and the presence of inhibitors [4].

The high demand of proteases in industries brings the attention of researchers to explore novel sources for proteases where isolation, screening and characterization of new promising strains are a continuous process [5]. Population increase, rapid urbanization, booming economy, and the rise in the standard of living in developing countries have greatly accelerated the rate, amount and quality of the municipal solid waste generation

A better yield of enzymes at the industrial scale in Nigeria can be achieved by isolating novel strains with an inherent capacity for enzyme production by process optimization or by improving the strains that are already being used [6]. Indigenous enzyme production will help in the creation of jobs by converting wastes to wealth and also conservation of foreign exchange. In order to curtail the challenge of enzyme production cost, the use of agro-waste materials as a source of carbon in place of expensive carbon sources such as molasses, corn starch and glucose could bring significant commercial success in biotechnological enzyme production [3]. These agricultural wastes can be used as substrates for enzyme production due to their availability and higher biomass [7]. Their proper use can also help in solving pollution problems which may be caused by their disposal.

Waste may be generated during the extraction of raw materials, the processing of raw materials into intermediate and final products, the consumption of final products from households, and other human activities [8]. When waste is dumped on land, microorganisms such as bacteria and fungi proliferate using the components of the waste materials as a source of nutrients for growth as well as degrading the organic materials in the waste [9]. These microorganisms degrade domestic wastes through their metabolic processes and this property of microbes has been exploited in bioprocess technology [10]. Hence, the aim of this study is to isolate, partially characterize and produce protease from domestic waste dumpsite isolates.

\subsection{Materials and Methods}

\subsection{Sample Collection}

The soil sample was collected in a sterile polythene bag from domestic wastes dumpsite at Zungeru, Niger State, Nigeria and immediately transferred to the laboratory for the isolation of bacteria and fungi.

\subsection{Media, Chemical and Reagent}

Nutrient agar (NA), glucose, $0.87 \%$ sodium saline, $1 \% \mathrm{CaCO}_{3}, 70 \%$ and $95 \%$ alcohol, crystal violet $(0.1 \mathrm{~g})$, gram's iodine $(0.18 \mathrm{~g})$, saffranine $(0.2 \mathrm{~g})$, glycerine, $3 \% \mathrm{KOH}$, Malachite green $(0.5 \mathrm{~g})$, carbolfuchsin stain, hydrochloride acid (conc. $3 \mathrm{ml}$ ), methylene blue chloride $(0.3 \mathrm{~g})$ beef extract $(0.3 \%)$, zinc chloride $(1 \mathrm{~g})$, potassium iodine $(0.1 \mathrm{~g})$, powdered zinc metal, yeast extract $(0.5 \mathrm{~g})$, $\mathrm{MgSO}_{4}(0.02 \mathrm{~g}), \mathrm{K}_{2} \mathrm{HPO}_{4}(0.1 \mathrm{~g}), \mathrm{NaCl}(0.5 \mathrm{~g})$, methyl red $(0.008 \mathrm{~g})$, tryptone $(1 \mathrm{~g})$, potassium phosphate $(0.5 \%)$, sodium citrate $(0.2 \mathrm{~g})$, agar $(1.5 \mathrm{~g})$, bromomethyl blue $(0.08 \mathrm{~g})$, $(\mathrm{NH} 4) \mathrm{H}_{2} \mathrm{PO}_{4}(0.1 \mathrm{~g})$.

\subsection{Isolation of microorganism}

One gram (1gm) of soil sample was mixed with $9 \mathrm{ml}$ of saline solution (Master dilution) and $1 \mathrm{ml}$ of the solution was serially transferred to tubes containing $9 \mathrm{ml}$ saline each so that for each transfer the suspension was diluted 10times. Each tube was shaken vigorously. $0.1 \mathrm{ml}$ solution was spread to Petri plates containing sterilized nutrient agar and saboroud dextrose agar for bacterial and fungal isolation. The pure isolates were stored in bottles for further studies.

\subsection{Screening for proteolytic activity}

The isolates obtained from the domestic waste dump site were spread on Petri plates containing milk agar medium ( $\mathrm{pH} \mathrm{7)}$ and incubated for $24 \mathrm{~h}$ at $37^{\circ} \mathrm{C}$ and 5 days at $25^{\circ} \mathrm{C}$ for bacterial and fungal isolates respectively. A clear zone of skim milk hydrolysis indicated protease producing organisms. Colonies showing proteolytic activity were selected for protease enzyme production [11].

Citation: Tsado A. N., Jiya, A.G., Ibrahim, A.H., Gana, D., Zubairu, R., Danazumi, N., Mohammed, A.S., Aliyu, M., and Akinniran, C.S. (2021). Production and partial characterization of protease from Pseudomonas aeruginosa and Bacillus subtilis isolated from domestic waste dumpsite. AROC in Pharmaceutical and Biotechnology, $01(01) ; 26-33$ 


\subsection{Identification of Proteolytic Bacteria Isolated from Soil}

The selected potential strain was then identified by morphological and biochemical characteristics by using a microbiology laboratory manual [12]

\subsection{Production of Protease Enzyme by Submerged Fermentation}

Protease production was carried out by inoculating protease producing isolate into a basal medium $\left(\mathrm{NH}_{4} \mathrm{Cl}-0.5 \%, \quad \mathrm{NaCl}-0.5 \%, \quad \mathrm{CaCl}_{2}-0.2 \%\right.$, $\mathrm{MgCl}_{2} .6 \mathrm{H}_{2} \mathrm{O}-0.2 \%, \mathrm{~K}_{2} \mathrm{HPO}_{4}-0.4 \%, \mathrm{KH}_{2} \mathrm{PO}_{4} 0.3 \%$ ) containing $0.7 \%$ peptone and $0.5 \%$ as nitrogen and carbon source respectively. The mixture was adjusted to $\mathrm{pH} 7.5$ and maintained at $37^{\circ} \mathrm{C}$ on a shaker at $250 \mathrm{revs} / \mathrm{min}$ for 96 hours. Samples were withdrawn and centrifuged every 12 hours and the supernatant was regarded as a crude protease enzyme [13].

\subsection{Determination of Protease Enzyme Activity}

The activity of protease was assessed in triplicate by measuring the release of trichloroacetic-acid soluble peptides from $0.5 \%(\mathrm{w} / \mathrm{v})$ casein in Tris- $\mathrm{HCl}(\mathrm{pH}$ 9.0) at $60 \cdot \mathrm{C}$ for $10 \mathrm{~min}$. The $1 \mathrm{~mL}$ reaction was terminated by adding $0.5 \mathrm{~mL}$ of $10 \%$ trichloroacetic acid. It was left for $15 \mathrm{~min}$ and then centrifuged at $14000 \mathrm{~g}$ for $10 \mathrm{~min}$. One unit of enzyme activity was defined as the amount of enzyme required to release $1 \mu \mathrm{g}$ of tyrosine/min under standard conditions [14].

\subsection{Determination of Kinetic Parameters of Protease Enzyme}

Factors affecting proteases activities such as $\mathrm{pH}$, temperature and substrate concentration were determined

\subsection{Effect of pH on protease activity}

The effect of $\mathrm{pH}$ on enzyme activity was carried out by incubating the reaction mixture at $40^{\circ} \mathrm{C}$ over a $\mathrm{pH}$ range of 4-9. This was achieved using various buffers at different $\mathrm{pH}$ ranges; $0.05 \mathrm{M}$ sodium citrate buffer ( $\mathrm{pH} 4-6)$ and $0.05 \mathrm{M}$ Tris- $\mathrm{HCl}(\mathrm{pH} \mathrm{7-9)}$. Then the enzyme activity was determined by the standard enzyme assay.

\subsection{Effect of temperature on protease activity}

The effect of temperature on enzyme stability was carried out by incubating the reaction mixture over a varied temperature of 30 to $80^{\circ} \mathrm{C}$ at a predetermined $\mathrm{pH}$. Then the enzyme activity was determined by the standard enzyme assay.

\subsection{Effect of substrate concentration on protease activity}

Effect of substrate concentration on protease activity was determined in reaction mixtures containing varied concentrations of casein solution $(\mathrm{mg} / \mathrm{ml}) ; 2.5, \quad 5.0,10.0,25.0,30.0,35.5$. Michaelis-Menten constant $(\mathrm{Km})$ and maximum velocity (Vmax) of protease were calculated from the plotted graph of $1 / \mathrm{V}_{0}$ against [1/S.

\subsection{Results}

\subsection{Identification of the microorganisms}

A total of 11 isolates obtained from the domestic waste dump site were screened on skim milk agar plates to have proteolytic activity and all of them were confirmed for protease production on further screening by submerged fermentation. The isolates code DDS3A and DDS2B were selected and identified to be $P$. aeruginosa and $B$. subtilis respectively (Table 1 ).

Table 1: Biochemical profile of the isolated organism

\begin{tabular}{lll}
\hline Isolate Code & DDS3A & DDS2B \\
\hline Gram reaction & & + \\
Shape & Rods & Rods \\
Catalase & - & + \\
Coagulase & - & - \\
$\begin{array}{l}\text { Starch } \\
\text { hydrolysis }\end{array}$ & - & + \\
$\begin{array}{l}\text { Oxidase } \\
\text { Mannitol salt }\end{array}$ & + & - \\
agar & - & - \\
Citrate test & + & + \\
$\begin{array}{l}\text { Urease test } \\
\text { Methyl Red }\end{array}$ & - & - \\
Vogue & - & - \\
$\begin{array}{l}\text { Proskauer } \\
\text { Indole }\end{array}$ & & + \\
Isolates & - & \\
\hline
\end{tabular}

Citation: Tsado A. N., Jiya, A.G., Ibrahim, A.H., Gana, D., Zubairu, R., Danazumi, N., Mohammed, A.S., Aliyu, M., and Akinniran, C.S. (2021). Production and partial characterization of protease from Pseudomonas aeruginosa and Bacillus subtilis isolated from domestic waste dumpsite. AROC in Pharmaceutical and Biotechnology, $01(01) ; 26-33$ 


\subsection{Optimization of protease production}

The optimum temperature values of proteases produced from Pseudomonas aeruginosa and Bacillus subtilis were both recorded at $50{ }^{\circ} \mathrm{C}$ (figure 1 ). The optimum $\mathrm{pH}$ values of proteases produced from Pseudomonas aeruginosa and Bacillus subtilis were both recorded at 8.0 and 9.0 respectively (figure 2). The $\mathrm{V}_{\max }$ and $\mathrm{K}_{\mathrm{m}}$ of protease produced from Pseudomonas aeruginosa were $222.22 \mathrm{U} / \mathrm{ml}$ and $0.625 \mathrm{mg} / \mathrm{ml}$ respectively (figure 3 ) while the $V_{\max }$ and $\mathrm{K}_{\mathrm{m}}$ of protease produced from $B$. subtilis were $135.13 \mathrm{U} / \mathrm{ml}$ and $0.402 \mathrm{mg} / \mathrm{ml}$ respectively (figure 4).

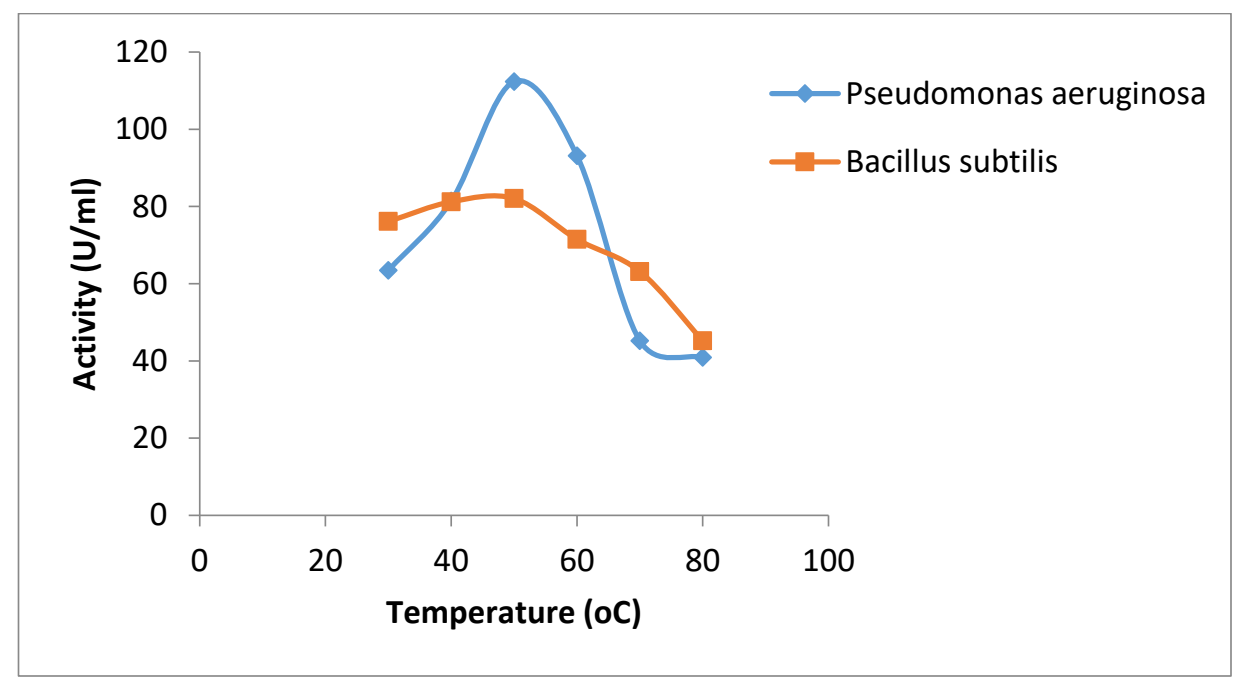

Figure 1: Temperature profile of proteases produced from Pseudomonas aeruginosa and Bacillus subtilis isolated from domestic waste dumpsite

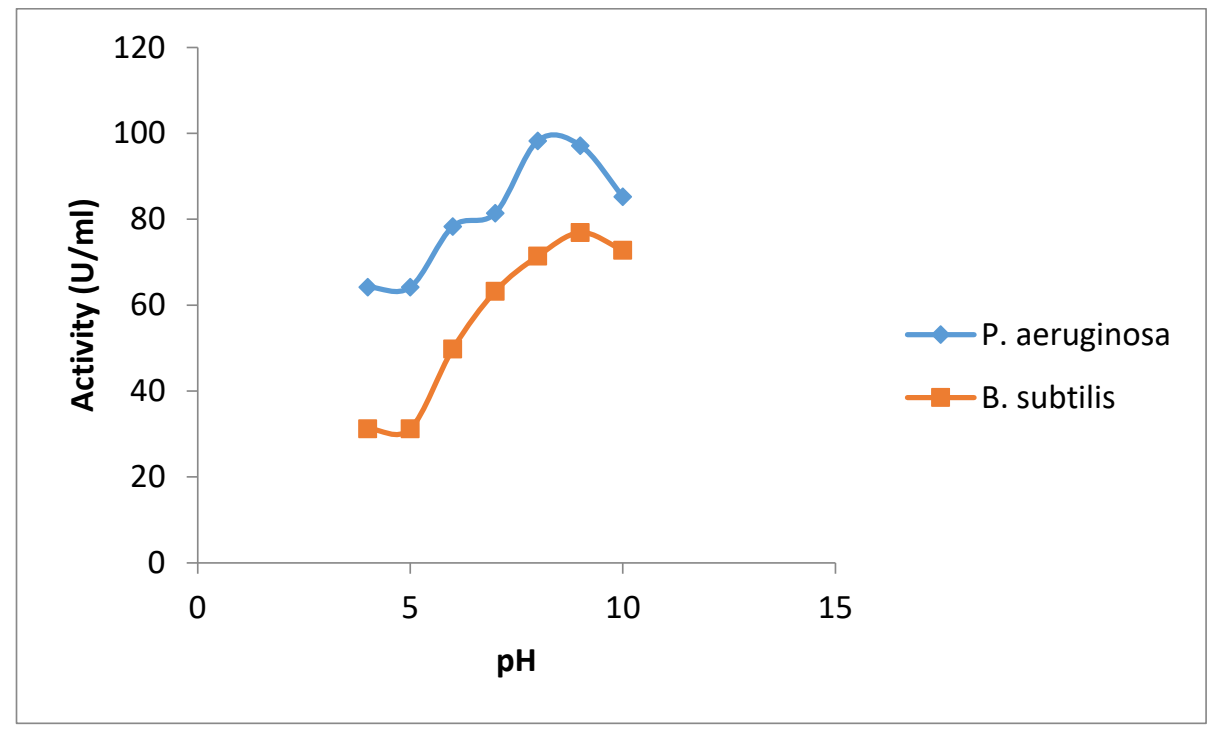

Figure 2: $\mathrm{pH}$ profile of protease produced from Pseudomonas aeruginosa and Bacillus subtilis isolated from domestic waste dumpsite

Citation: Tsado A. N., Jiya, A.G., Ibrahim, A.H., Gana, D., Zubairu, R., Danazumi, N., Mohammed, A.S., Aliyu, M., and Akinniran, C.S. (2021). Production and partial characterization of protease from Pseudomonas aeruginosa and Bacillus subtilis isolated from domestic waste dumpsite. AROC in Pharmaceutical and Biotechnology, 01(01);26-33 


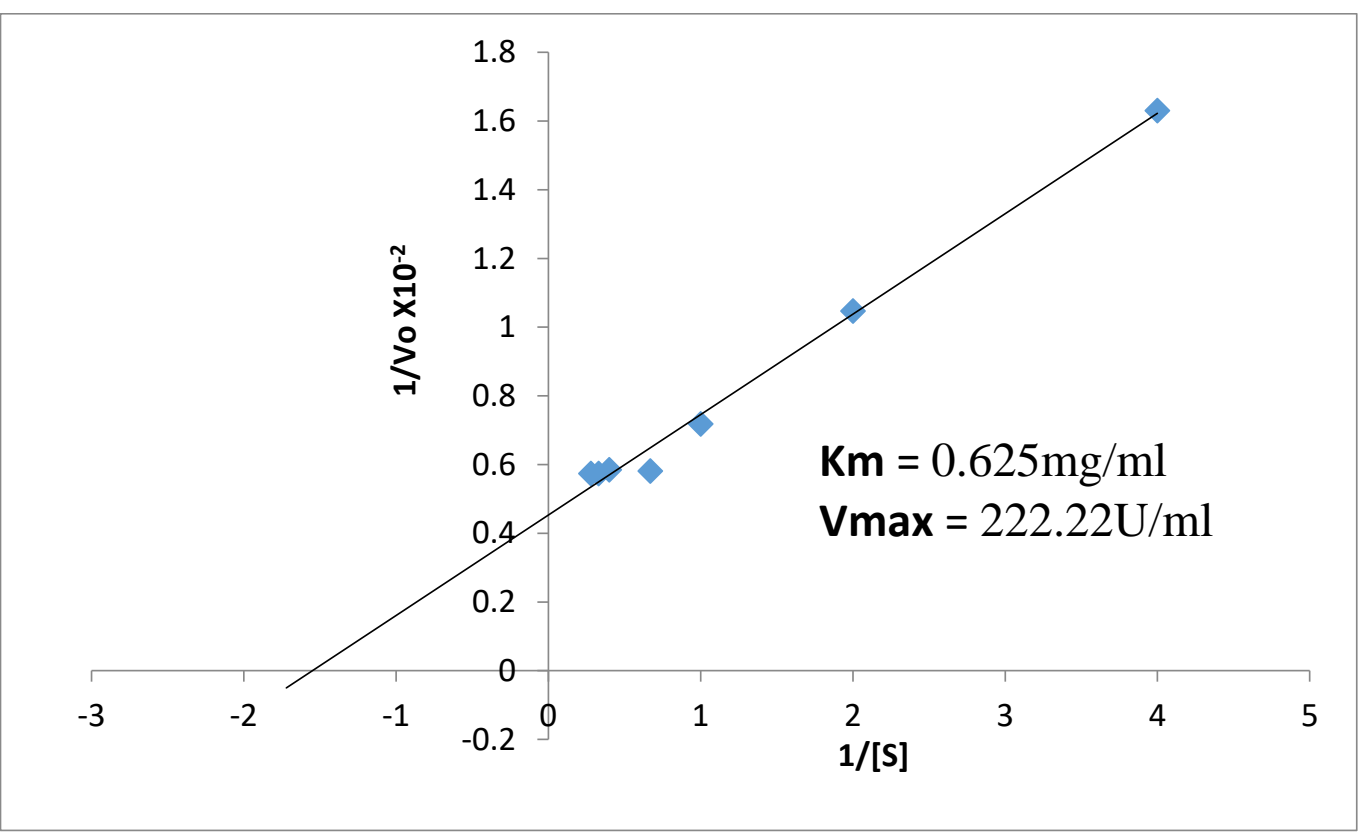

Figure 3: Effect of substrate concentration on the activity of protease produced from Pseudomonas aeruginosa isolated from domestic waste dump site

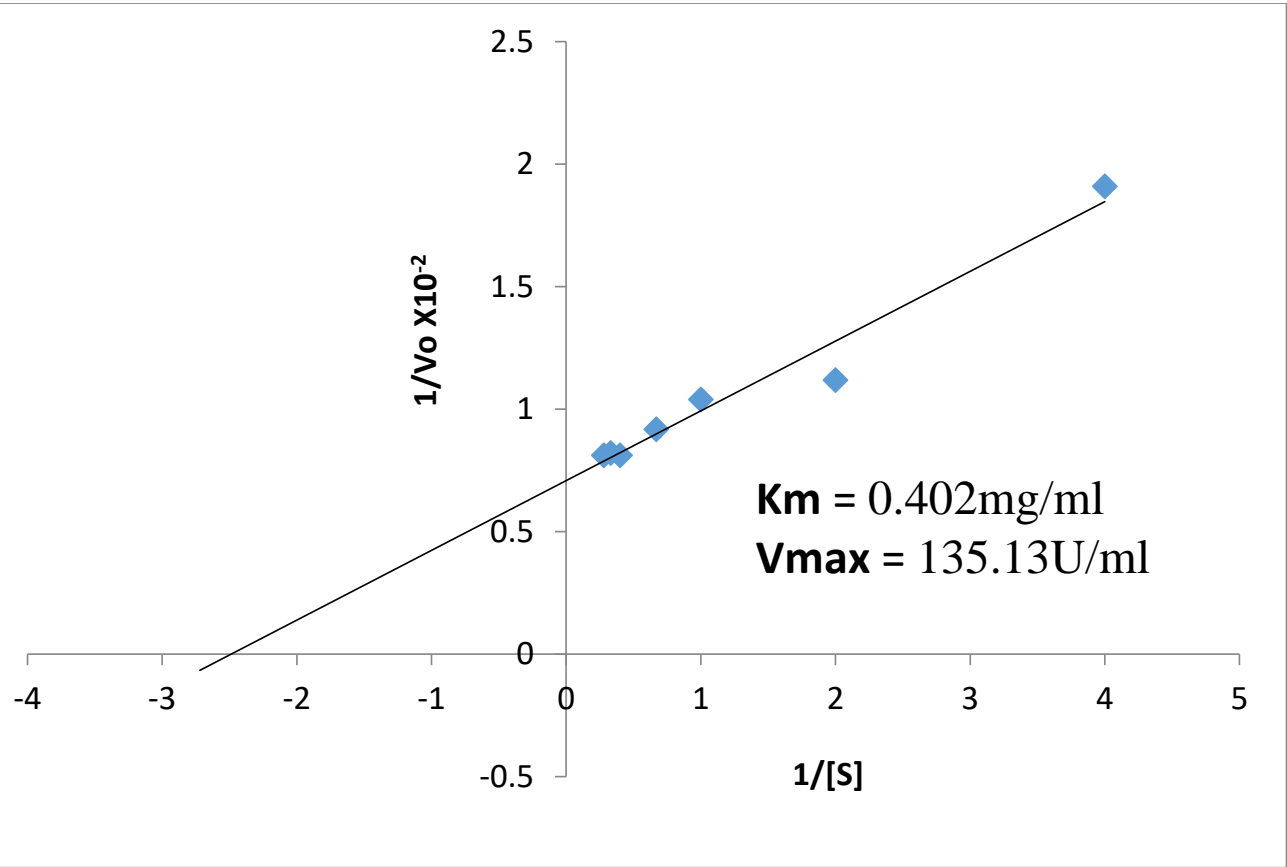

Figure 4: Effect of substrate concentration on the activity of protease produced from $B$. subtilis isolated from domestic waste dumpsite. 


\subsection{Discussion}

Among the isolates obtained from the domestic dumpsite, isolates DDS3A and DDS2B were found to have a significant positive effect in the degradation of the protein (skimmed milk) and thus indicating good potential for the production of protease enzyme. These isolates were identified to be Pseudomonas aeruginosa and Bacillus subtilis respectively and were selected for protease production. The presence of these proteolytic isolates in domestic waste dumpsites depends greatly on the protein waste components arising from kitchen or food remnants. These bacteria are actively involved in the degradation of protein constituents of domestic waste, thereby making the dumpsite a natural habitat. They used the waste protein as their major source of nitrogen for extracellular protease production necessary for further protein degradation [15]. Proteolytic bacteria were also isolated by other researchers from landfills and biodegradable portions of domestic waste $[16,17]$. The findings of the present study thus show that domestic waste dumpsite could be considered a good source of proteolytic bacteria.

Enzyme characterization is important for industrial applications of the enzyme. The optimum temperature values of proteases produced from Pseudomonas aeruginosa and Bacillus subtilis were both recorded at $50{ }^{\circ} \mathrm{C}$ (figure 1). A decrease in enzyme activity at a temperature beyond this point could be due to enzyme denaturation. Haddar et al. [18] reported that the constant and highest protease enzyme activity was observed at a temperature between $25-60^{\circ} \mathrm{C}$ when using casein as substrate. Most reported protease enzymes presented their maximum rates in the range of $30-85^{\circ} \mathrm{C}$ [19]

The optimum $\mathrm{pH}$ values of proteases produced from Pseudomonas aeruginosa and Bacillus subtilis were both recorded at 8.0 and 9.0 respectively (figure 2 ). These results suggest domestic dumpsite as a potential source of alkaline protease for industrial application. The decline in enzyme activity could be a result of conformational change in protein three-dimensional structures at extreme $\mathrm{pH}$ values. The optimum catalytic activity from different proteases reported is in the range of $\mathrm{pH}$ 7-11 [11,20,21].

The $V_{\max }$ and $\mathrm{K}_{\mathrm{m}}$ of protease produced from Pseudomonas aeruginosa were $222.22 \mathrm{U} / \mathrm{ml}$ and $0.625 \mathrm{mg} / \mathrm{ml}$ respectively (figure 3 ) while the $V_{\text {max }}$ and $\mathrm{K}_{\mathrm{m}}$ of protease produced from $B$. subtilis were $135.13 \mathrm{U} / \mathrm{ml}$ and $0.402 \mathrm{mg} / \mathrm{ml}$ respectively (figure 4 ). The relationship between the rate of reaction and concentration of substrate depends on the affinity of the enzyme for its substrate expressed as $\mathrm{Km}$ of protease enzyme [22]. Ahmed et al. [19] reported that the catalytic properties, $\mathrm{Km}$ and $\mathrm{Vmax}$ values of alkaline protease from Bacillus subtilis were $58 \mu \mathrm{M}$ and 148 $\mathrm{U} / \mathrm{mL}$, respectively. An enzyme with low $\mathrm{Km}$ has a greater affinity for its substrate. Alkaline protease is highly substrate-specific and exhibits maximum activity towards casein as substrate.

\subsection{Conclusion}

From the present study, it is concluded that the identified species, Pseudomonas aeruginosa and Bacillus subtilis isolated from domestic waste dumpsite possess good protease activity. This domestic waste dumpsite is suggested to be a good source of proteolytic isolates. The alkaline proteases produced in this study may be used for various purposes in detergent industries, food industries and pharmaceutical industries owing to their high optimum temperature and alkaline $\mathrm{pH}$ values along with their high $\mathrm{V}_{\max }$ and substrate specificity.

Author Contributions: The work was conducted in collaboration of all authors. All authors have read and agreed to the published version of the manuscript.

Funding: This work received no external funding

Institutional Review Board Statement: Not Applicable.

Informed Consent Statement: Not Applicable.

Acknowledgments: Not Applicable

Conflicts of Interest: The authors declare that no conflict of interest exists.

\section{References}

Citation: Tsado A. N., Jiya, A.G., Ibrahim, A.H., Gana, D., Zubairu, R., Danazumi, N., Mohammed, A.S., Aliyu, M., and Akinniran, C.S. (2021). Production and partial characterization of protease from Pseudomonas aeruginosa and Bacillus subtilis isolated from domestic waste dumpsite. AROC in Pharmaceutical and Biotechnology, $01(01) ; 26-33$ 
1. Nnolim, N.E.; Okoh, A.I.; Nwodo, U.U. Proteolytic bacteria isolated from agro-waste dumpsites produced keratinolytic enzymes. Biotechnology Reports 2020, 27, e00483.

2. Kandasamy, S.; Muthusamy, G.; Balakrishnan, S.; Duraisamy, S.; Thangasamy, S.; Seralathan, K.-K.; Chinnappan, S. Optimization of protease production from surface-modified coffee pulp waste and corncobs using Bacillus sp. by SSF. 3 Biotech 2016, 6, 1-11.

3. Sarita, A.; Neeraj, W. Degradation of chicken feather a poultry waste product by Keratinolytic bacteria isolated from dumping site at Ghazipur poultry processing plant. International Journal of Poultry Science 2010, 9, 482-489.

4. Hrynkiewicz, K.; Baum, C.; Leinweber, P. Density, metabolic activity, and identity of cultivable rhizosphere bacteria on Salix viminalis in disturbed arable and landfill soils. Journal of Plant Nutrition and Soil Science 2010, 173, 747-756.

5. Bose, A.; Pathan, S.; Pathak, K.; Keharia, $\mathrm{H}$. Keratinolytic protease production by Bacillus amyloliquefaciens $6 \mathrm{~B}$ using feather meal as substrate and application of feather hydrolysate as organic nitrogen input for agricultural soil. Waste and biomass valorization 2014, 5, 595-605.

6. Oyeleke, S.; Egwim, E.C.; Auta, S. Screening of Aspergillus flavus and Aspergillus fumigatus strains for extracellular protease enzyme production. Journal of Microbiology and Antimicrobials 2010, 2, 83-87.

7. Reddy, G.S.; Pranavi, S.; Srimoukthika, B.; Reddy, V.V. Isolation and characterization of bacteria from compost for municipal solid waste from Guntur and Vijayawada. Journal of Pharmaceutical Sciences and Research 2017, 9, 1490.

8. Swain, P.K. Utilisation of agriculture waste products for production of bio-fuels: a novel study. Materials Today: Proceedings 2017, 4, 1195911967.

9. Bharathiraja, S.; Suriya, J.; Krishnan, M.; Manivasagan, P.; Kim, S.-K. Production of enzymes from agricultural wastes and their potential industrial applications. In Advances in food and nutrition research, Elsevier: 2017; Vol. 80, pp. 125148.

10. Kumla, J.; Suwannarach, N.; Sujarit, K.; Penkhrue, W.; Kakumyan, P.; Jatuwong, K.; Vadthanarat, S.; Lumyong, S. Cultivation of mushrooms and their lignocellulolytic enzyme production through the utilization of agro-industrial waste. Molecules 2020, 25, 2811.

11. Batra, N.; Walia, M. Production and characterization of alkaline protease from bacteria strains isolated from cotton field. African Journal of Microbiology Research 2014, 8, 702-709.

12. Cheesbrough, M. District laboratory practice in tropical countries, part 2; Cambridge university press: 2005.

13. Arunachalam, C.; Saritha, K. Protease enzyme: an eco-friendly alternative for leather industry. Indian Journal of Science and Technology 2009, 2, 29-32.

14. Joo, H.-S.; Kumar, C.G.; Park, G.-C.; Kim, K.T.; Paik, S.R.; Chang, C.-S. Optimization of the production of an extracellular alkaline protease from Bacillus horikoshii. Process Biochemistry 2002, 38, 155-159.

15. Zaved, H.K.; Rahman, M.M.; Rahman, M.M.; Rahman, A.; Arafat, S.; Rahman, M.S. Isolation and characterization of effective bacteria for solid waste degradation for organic manure. Current Applied Science and Technology 2008, 8, 44-55.

16. Gomez, A.M.; Yannarell, A.C.; Sims, G.K.; Cadavid-Restrepo, G.; Herrera, C.X.M. Characterization of bacterial diversity at different depths in the Moravia Hill landfill site at Medellín, Colombia. Soil Biology and Biochemistry 2011, 43, 1275-1284.

17. Emimol, A.; Ganga, G.; Parvathy, R.; Radhika, G.; Nair, G. Screening of microbes producing extracellular hydrolytic enzyme from corporation waste dumping site and house hold waste for the enhancement of bioremediation methods. IOSR-JPBS 2012, 4, 54-60.

Citation: Tsado A. N., Jiya, A.G., Ibrahim, A.H., Gana, D., Zubairu, R., Danazumi, N., Mohammed, A.S., Aliyu, M., and Akinniran, C.S. (2021). Production and partial characterization of protease from Pseudomonas aeruginosa and Bacillus subtilis isolated from domestic waste dumpsite. AROC in Pharmaceutical and Biotechnology, $01(01) ; 26-33$ 
18. Haddar, A.; Agrebi, R.; Bougatef, A.; Hmidet, N.; Sellami-Kamoun, A.; Nasri, M. Two detergent stable alkaline serine-proteases from Bacillus mojavensis A21: purification, characterization and potential application as a laundry detergent additive. Bioresource Technology 2009, 100, 3366-3373.

19. Ahmed, I.; Zia, M.A.; Iqbal, H.N. Purification and kinetic parameters characterization of an alkaline protease produced from Bacillus subtilis through submerged fermentation technique. World Applied Sciences Journal 2011, 12, 751-757.

20. Kocabiyik, S.; ÖZDEMIR, I. Purification and characterization of an intracellular chymotrypsinlike serine protease from Thermoplasma volcanium. Bioscience, biotechnology, and biochemistry 2006, 70, 126-134.
21. Vidyasagar, M.; Prakash, S.; Sreeramulu, K. Optimization of culture conditions for the production of haloalkaliphilic thermostable protease from an extremely halophilic archaeon Halogeometricum sp. TSS101. Letters in applied microbiology 2006, 43, 385-391.

22. Arulmani, M.; Aparanjini, K.; Vasanthi, K.; Arumugam, P.; Arivuchelvi, M.; Kalaichelvan, P.T. Purification and partial characterization of serine protease from thermostable alkalophilic Bacillus laterosporus-AK1. World Journal of Microbiology and Biotechnology 2007, 23, 475-481.

\footnotetext{
Submit your article to AROC JOURNALS

-AROC in Pharmaceutical and Biotechnology -AROC in Agriculture

-AROC in Food and Nutrition

-AROC in Natural Product Research

-BIOMED Natural and Applied Science

Via https://arocjournal.com/

Citation: Tsado A. N., Jiya, A.G., Ibrahim, A.H., Gana, D., Zubairu, R., Danazumi, N., Monammed, A.S., AlIyu, M., ana AKInnIran, C.S. (LUZ1). Production ana partial characterization of protease from Pseudomonas aeruginosa and Bacillus subtilis isolated from domestic waste dumpsite. AROC in Pharmaceutical and Biotechnology, $01(01) ; 26-33$
} 